\title{
Analysis of Business External Factors that Impact the Growth of IT Entrepreneurship
}

\author{
Rajib Kumar Roy ${ }^{1}$, Dr. R. Duraipandian² \\ ${ }^{1} \mathrm{PhD}$. Scholar, School of Commerce \& Management, Garden City, University, Bangalore. \\ ${ }^{2}$ Professor \& Research Supervisor, School of Commerce \& Management, Garden City, University, Bangalore. \\ Email: ${ }^{1}$ racehorseind@gmail.com, ${ }^{2}$ duraipandian.r@gardencity.university.
}

\begin{abstract}
the aim of this study is to find out the impact of business External factors towards the business growth for IT entrepreneurships in Bangalore Sample is collected from 200 individuals associated with IT entrepreneurships of Bangalore. We have undertaken the External factors like social acceptance of business, economic condition, technological factor, local culture, Legalities, competitive factor, role of local political environment, media, supply of work force, demography, business location, climate, low and order, corruptions. We have taken business growth for 3 years as measurement of success factors for the business. During study it was identified that business External factors i.e. economic condition, media, competitive factor has significant impact on business success.
\end{abstract}

Keywords

Business External Factor, Business Growth

Article Received: 02 November 2020, Revised: 24 November 2020, Accepted: 18 December 2020

\section{Introduction}

During Entrepreneurship development and formulation, there are multiple analysis undergoes to identify the strength of the business. Every business ecosystem has two forces acting, one from business inside and another from external. The success of the business depends upon how business leaders understand and creatively exploit the ecosystem external factors.

Business external factors plays major role during Idea development, creation of simplified business process, business model development which intern become the DNA of business and leadership strategy.

Understanding external factor help any business to streamline the business strategy. An effective business strategy and leadership always focus on reduction of Risk, Rework and winning competitive market through right quality of solution. This does help in increasing productivity, reliability and ensure a stronger return on investment.

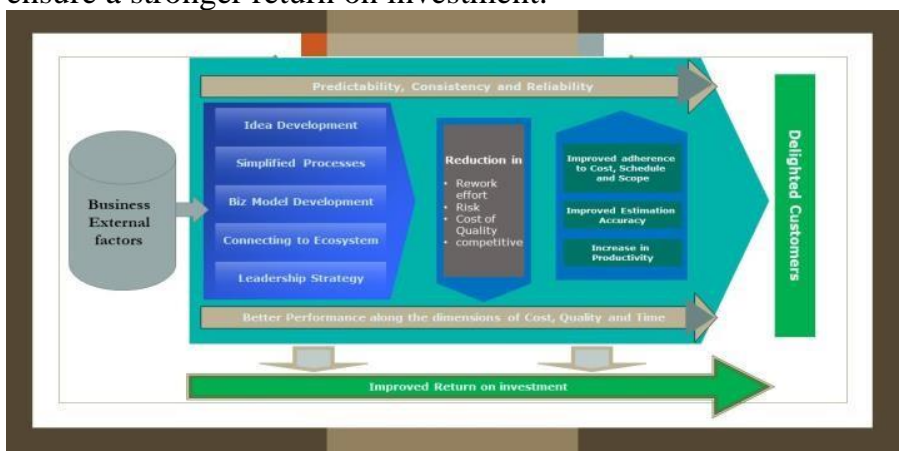

Pic 1: Business External Factor's relationship with business

During the study we have identified 14 business external factors which has variant impact in entrepreneurships and related ecosystem.

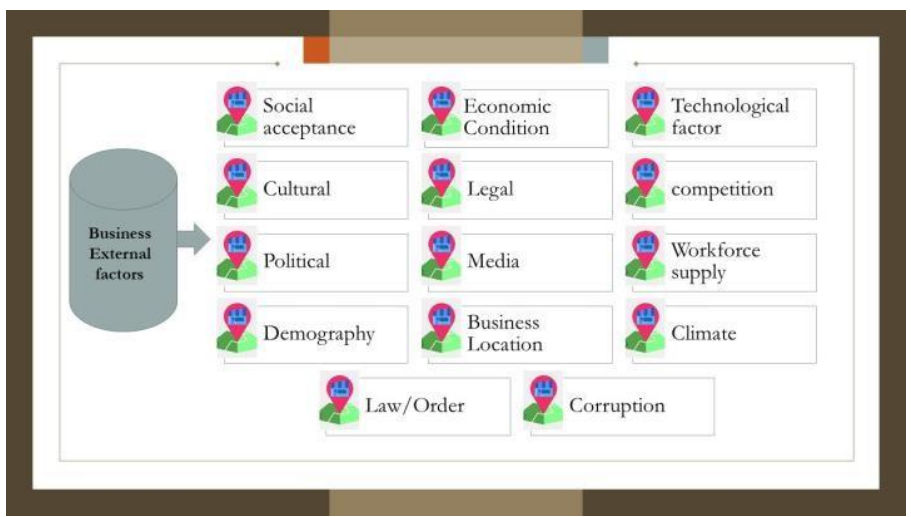

Pic 2: 14 in scope Business External factors

The magnitude of effect of each factor depends upon the perceived impact each company is facing during business executing and previous experience of handling the same.

\section{Literature review}

The external factor analysis for any business identify the entrepreneur's external environment as suggested by Boardman et al. (2004). Suggested that, the external environment is divided into macro-environment and microenvironment. The factors of such environments are having varying perceived impact to the business potential. To create the business strategy it is important to identify the strategic behaviors and it is necessary to conduct macro and micro analysis of every business ecosystem. For an effective identification of the micro external environment Boardman et al. (2004) and Johnson et al. (2008) suggest using the five forces framework developed by Porter (1980). Austin (1990), adds four influential macro factors to Porter's original five forces framework.

The four factors include: economic, political, cultural and demographic factors. These factors are similar to the factors in the PESTEL-framework (political, economic, social, 
technological. The combination of micro and macro factors are depending upon the market where the business is being operated.

While evaluating the business external factors which will have impact on business performance and success, we have undertaken the Economic, Psychological, Sociological, Anthropological, Opportunity-Based, Resource-Based theories to identify the factors effecting ecosystem.

Based on the classical theory extolled the virtues of free trade, specialization, and competition (Ricardo, 1817; Smith, 1776).The theory was the result of Britain's industrial revolution which took place in the mid 1700 and lasted until the 1830s. The classical movement described the directing role of the entrepreneur in the context of production and distribution of goods in a competitive marketplace (Say, 1803). Classical theorists articulated three modes of production: land; capital; and labor

In the Technology Entrepreneurship Ecosystem in India: Findings from a Survey by Ruchita Gupta1, Karuna Jain1

,AnandKusre2, Kirankumar S. Momaya of National Institute of Industrial Engineering (NITIE), In this journal, the researchers identified environmental ( creating change to provide jobs, being own boss, exploration of talent, eagerness to earn high income, passion, location of the business, market of the solution offered ) and individual factors (leadership, networking, risk taking ability, business and technical knowledge) affecting the technology entrepreneurships success.

The environmental and individual factors have a strong impact on the motive of building an entrepreneurship as need to be seen as a socio improvement and betterment of life. The individual factors help an entrepreneur to shape up the strategy, approach for the business and building an ability to delivery right solution for business market. Though this analysis didn't show the correlation of the business factors of success.

In the book "Why Startups Fail And What You Can Do To Beat the odds"...by Meszaros, George identified that not one reason behind the unsuccessful startup, but multiple reasons contributes the failure of a startup.

- Sometime too many or too few founders are the biggest possible reasons, in ideal case they should complement to each other in skill set and should be able to leverage the competencies.

- Creation of business without an involvement of customer base and competition.

- Business without a robust system (marketing, production, training, quality, service) in place

- Not having right resources who can be the best fit for job and a good performer

- Usage of right investment, from right investor for right cause (with a strategic partnership)

- $\quad$ Creation and judge under uneven competition

- $\quad$ Good mentorship \& leadership

In the book of "WHY STARTUPS FAIL AND HOW YOURS CAN SUCCEED” by David Feinleib

This book describe that a market fit product is very much important to ensure the success of the solution, Identifying the right balance between the consumer expectation and the product is always done through right understanding by the team. Targeting small markets, not analyzing correct data from market, uneven thesis, taking too much time to reach market and going against wave will hurt any entrepreneurship. This book also discussed that, focus should be creation of right product with a strong and futuristic vision, and with a strong user base. This will help product to evolve faster and better for right market.

An entrepreneur should have a strong market sense with a right vision, should have ability to create a new market or change a market with innovative idea, should be able to deliver on time addressing the need of time and market. A quick learner from market and failures.

Sales and marketing play a major role to project right solution to consumer face. Usage of innovative sales and creation of brand reputation play major role in overall success. Sales should be an integral part of company's mission.

Strong communication to market the entrepreneurship and it's brand value play vital role in consumer acceptance. The project execution, right time entry to market plays a very vital role for success.

John Rampton expressed the possible reason where entrepreneurs will lose out of ground in

\section{- $\quad$ No proof of Success}

- Having an inexperienced team

- No structured business models, without any focus

- An inefficient and "closed mind" CEO

- $\quad$ Poor handling of feedbacks

- $\quad$ No strong understanding about industry / market

- $\quad$ No strong sales propositions

In RESEARCH BRIEFS, they have shown the top reasons for entrepreneurship failures as Based on analysis of 101 startup post-mortem

\section{- $\quad$ No Market Need: \\ - Running out of Cash: \\ - Not the right team at work: \\ - Out of competition: \\ - $\quad$ Pricing and cost issue: \\ - User unfriendly product}

In the journal, Factors that Positively Influence the Initiation of a Business by Alice Reissová, Jana Šimsová, Kateřina Kovářová, Radek Šimanovský

The research has shown the below factors influence entrepreneurship with regards to the question if they wanted to start a business or not. The answer is strongly influenced by

- $\quad$ Family tradition (children continue with parent's business)

- $\quad$ Young people do not want to be managed by anybody

- $\quad$ Possibility of business incubation centers

- Sufficiency of finance during the initiation of business

- Own business space

- $\quad$ Subjects during their studies

In Forbes journal list, David skok shows 5 top reasons for entrepreneurships to fail as "5 Reasons Start-ups Fail"

- $\quad$ Market problem

- $\quad$ Business model failure

- $\quad$ Poor Management Team

- $\quad$ Running out of Cash 


\section{- $\quad$ Product or solution Problem}

In the above cases either small market or no market is an potential issue for aligning product to consumer base. And business models trying to access customers easily gives them a Hardaway to move forward. In many cases the cost of acquiring the customer (CAC) is actually higher than the lifetime value of that customer (LTV). Poor management team fails to identify right market and handle the risk of nonpenetrating market or create right strategy. Due to which they might run out of cash or might not have spent in right format for all the business areas based on importance of cash allocation. And the rest turnout to be not having right solution/product for actual consumer base and/or developed wrong product.

Methodology: The aim was to analyze the business External factors which has impact on IT business performance and success. Following the objective, the below hypothesis was made

\section{Ho: There is no influence of business External factors on growth of IT entrepreneurship}

Ha: There is strong influence of External factors on growth of IT entrepreneurship

During the research, confidence level of $95 \%$ is identified from population. It was identified that 200 should be the sample size for analysis. Data collected from senior stakeholder of companies from operation, management, founder groups.

We identified the factors which has influence on entrepreneurships are

- Social acceptance of business: bringing the combination of solution to be a meaningful contribution to society

- $\quad$ Economic condition: this is a set of macro variables (GDP, Inflation, employment/unemployment rate/monetary policy etc.) which decide the state and trend of an economy

- Technological factor: this defines the set of practices (automation, GUI support etc.), equipment, which are used for any solution development,

- Local cultural factor: Understanding this factor helps understanding the values, need, want, acceptance, preferences which has strong influence over building company and/or understanding consumer behaviour

- Legal factor: Understanding this factor helps to knows the law protecting securities, asset, consumer, contract, employment, health and environment, wages etc.

- Competitive factor: Understanding this factor will help understanding the current competitors offers, the value additions, market wants, need and other expectations. Which helps any company to create unique selling feature into its product or services to attract the consumer base.

- Political factor: local government policy on public service, infrastructure, taxation, future vision help all companies to create strategic plan to get max benefit out of government policies and avoid unwanted hazard.

- Media: Media play major role to promote companies' vision, product, offers to demographic base, based on age, income, education etc. This also seen as a strong tool for consumer relation management and marketing/promotion.

- $\quad$ Supply of workforce: Supply of labor is the base for any company's long-term vision of serving a economy.
Potential labor arability help company to build its support/work force.

- Demography: understanding the consumer demography, it's size, composition, distribution, migration etc. help creating the solution/ offering to a business ecosystem.

- $\quad$ Business location: business location plays major role to connect to it's consumer for B2B or B2C. The nearest to consumer base help understanding and providing solution faster time frame. Right location also helps accessing the govt. facilities, labor, infrastructure etc.

- Local climate: Local climate plays major role to attract labors from other place, creating sustainable infrastructure, predictable deliveries, growth.

- Law \& Order: Understanding local law and order help companies to build protocol aligned to govt. regulations, policies and rule for local socio culture.

- Corruption: Corruption in business involves misappropriation of funds, bribery, misuse of office by company officials and dishonesty in financial matters. High corruption hurts the growth of economy and the sustainability towards employment, company mission.

been identified to collect the data. Likert scale-based survey is conducted through telephonic and email communication. Data collected using MS Excel and analysis processed we used SPSS.

\section{Research Methodology}

During the data collection we have taken data from 200 senior business stakeholder individuals of IT entrepreneurship companies. The position of the stakeholder's play major role in our analysis. We have chosen only senior stakeholder of the business as they have more visibility, understanding and control over formation of business, operation / execution. So, we have taken people from business, consulting, Human resource and operation, solution delivery, head of IT.

\begin{tabular}{|l|l|l|l|l|}
\hline & $\begin{array}{l}\text { Frequen } \\
\text { cy }\end{array}$ & $\begin{array}{l}\text { Percen } \\
\mathrm{t}\end{array}$ & $\begin{array}{l}\text { Valid } \\
\text { Percent }\end{array}$ & $\begin{array}{l}\text { Cumulativ } \\
\mathrm{e} \text { Percent }\end{array}$ \\
\hline Business head & 17 & 8.5 & 8.5 & 8.5 \\
Consulting head & 8 & 4.0 & 4.0 & 12.5 \\
Hr head & 28 & 14.0 & 14.0 & 26.5 \\
$\begin{array}{l}\text { Senior delivery } \\
\text { Vali manager } \\
\text { d Chief Business }\end{array}$ & 43 & 21.5 & 21.5 & 48.0 \\
$\begin{array}{l}\text { manager } \\
\text { Global IT lead }\end{array}$ & 49 & 18.0 & 18.0 & 66.0 \\
Director & 19 & 9.5 & 9.5 & 100.0 \\
Total & 200 & 100.0 & 100.0 & \\
\hline
\end{tabular}

Table: 1: Professional level of the participants

When we checked the overall qualification of the professionals which gave us a good level of confidence as higher and medium qualification has a good distribution. 


\section{Qualification}

\begin{tabular}{|c|l|l|l|l|}
\hline & $\begin{array}{l}\text { Frequenc } \\
\mathrm{y}\end{array}$ & Percent & $\begin{array}{l}\text { Valid } \\
\text { Percen } \\
\mathrm{t}\end{array}$ & $\begin{array}{l}\text { Cumulative } \\
\text { Percent }\end{array}$ \\
\hline $\begin{array}{c}\text { graduate } \\
\text { pg }\end{array}$ & 103 & 51.5 & 51.5 & 51.5 \\
Valid above & 26 & 135.5 & 35.5 & 87.0 \\
pg & 13.0 & 13.0 & 100.0 \\
Total & 200 & 100.0 & 100.0 & \\
\hline
\end{tabular}

Table: 2: Qualification level of the participants

During the data collection, we have taken 14 business External factors which we have shown above and We have taken two dependent variables namely

DV: Business grown for last 3 years

The dependent variables are tested against 14 parameters separately to identify if there is a significant relationship between them. The overall goal of the multiple regression is to validate if there are some factors which has more significant over others on companies' growth.

Ever traditional business, we consider the business growth as measurement of performance and core fundamental of a business health.

In our first analysis, we did the significance analysis of 14 External factors on Business Growth (DV).

$\mathrm{R}$-squared measures the proportion of the variation in our dependent variable (DV) by our independent variables for a linear regression model. Adjusted R-squared adjusts the statistic based on the number of independent variables in the model.

When we did regression analysis, we found the below result. In the above Anova and regression table the p-value is less than 0.05 for the bold values indicating that it is significant so we conclude that there is influence of business External factors on business growth over the past three years.

In our second analysis, we did the significance analysis of 11 External factors on Business growth (DV).

\section{Model Summary}

\begin{tabular}{ll|lll} 
Model & R & R Square & $\begin{array}{l}\text { Adjusted } \\
\text { Square }\end{array}$ & $\begin{array}{c}\text { R Std. Error of } \\
\text { the Estimate }\end{array}$ \\
\hline 1 & $.947^{\mathrm{a}}$ & .896 & .888 & .343 \\
\hline
\end{tabular}

Table: 3: Model summary

\section{ANOVA}

\begin{tabular}{|c|c|c|c|c|c|c|}
\hline \multicolumn{2}{|c|}{ Mode] } & \multirow{2}{*}{$\begin{array}{l}\text { Sum } \\
\text { Squares } \\
187.773\end{array}$} & \multirow{2}{*}{$\frac{\mathrm{f}}{\mathrm{df}}$} & \multirow{2}{*}{$\begin{array}{l}\text { Mean } \\
\text { Square } \\
13.412\end{array}$} & \multirow{2}{*}{\multicolumn{2}{|c|}{$\frac{F \quad \text { Sig. }}{113.706 .000^{b}}$}} \\
\hline 1 & $\begin{array}{l}\text { Regressio } \\
\mathrm{n}\end{array}$ & & & & & \\
\hline & Residual & 21.822 & 185 & .118 & & \\
\hline & Total & 209.595 & 199 & & & \\
\hline
\end{tabular}

Table: 4: Analysis of variance of 14 business External factors
When we did regression analysis, we found the below result. Coefficients $^{\mathrm{a}}$

\begin{tabular}{|c|c|c|c|c|c|}
\hline \multirow[t]{2}{*}{ Model } & \multicolumn{2}{|c|}{$\begin{array}{l}\text { Unstandardized } \\
\text { Coefficients }\end{array}$} & \multirow{2}{*}{\begin{tabular}{|l|}
$\begin{array}{l}\text { Standardi } \\
\text { zed } \\
\text { Coefficie } \\
\text { nts }\end{array}$ \\
Beta
\end{tabular}} & & \multirow[t]{2}{*}{ Sig. } \\
\hline & B & $\begin{array}{l}\text { Std. } \\
\text { Error }\end{array}$ & & & \\
\hline (Constant) & .207 & .248 & & .835 & .405 \\
\hline $\begin{array}{l}\text { 2Impact } \\
\text { Social } \\
\text { acceptance of } \\
\text { business }\end{array}$ & .010 & .031 & .011 & .332 & .740 \\
\hline Impact of & & & & 25.63 & \\
\hline $\begin{array}{l}\text { condition } \\
\text { conde }\end{array}$ & 1.001 & .039 & .944 & 3 & .000 \\
\hline Impact . of & & & & & \\
\hline $\begin{array}{l}\text { Technological } \\
\text { factors }\end{array}$ & -.128 & .039 & -.112 & $-3.264 \mid$ & .001 \\
\hline $\begin{array}{l}\text { Impact of local } \\
\text { Cultural factors }\end{array}$ & -.010 & .040 & -.008 & -.246 & .806 \\
\hline $\begin{array}{l}\text { Impact Legal } \\
\text { factors }\end{array}$ & -.084 & .038 & -.067 & -2.180 & .031 \\
\hline Impact of & & & & & \\
\hline $\begin{array}{l}\text { Competitive } \\
\text { factors }\end{array}$ & .088 & .039 & .072 & 2.277 & .024 \\
\hline $\begin{array}{l}\text { Impact of } \\
\text { Political factors }\end{array}$ & .023 & .026 & .023 & .882 & .379 \\
\hline $\begin{array}{l}\text { Impact } \\
\text { Media }\end{array}$ & .112 & .025 & .129 & 4.576 & .000 \\
\hline Impact & & & & & \\
\hline $\begin{array}{l}\text { Supply } \\
\text { workforce }\end{array}$ & .067 & .037 & .053 & 1.793 & .075 \\
\hline Impact of & & & & & \\
\hline $\begin{array}{l}\text { Demographical } \\
\text { situation }\end{array}$ & -.062 & .037 & -.051 & -1.665 & .098 \\
\hline $\begin{array}{l}\text { Importance of } \\
\text { business } \\
\text { Location }\end{array}$ & .021 & .029 & .022 & .742 & .459 \\
\hline $\begin{array}{l}\text { Importance of } \\
\text { local Climate }\end{array}$ & -.056 & .027 & -.055 & -2.100 & .037 \\
\hline $\begin{array}{l}\text { Importance of } \\
\text { maintaining } \\
\text { Law and Order }\end{array}$ & -.023 & .032 & -.027 & -.720 & .472 \\
\hline $\begin{array}{l}\text { Impact } \\
\text { Corruption }\end{array}$ & -.006 & .036 & -.006 & -.168 & .867 \\
\hline
\end{tabular}

a. Dependent Variable: DV@2Has the business has grown over the past three years ?

Table: 5: Coefficient of 14 business External factors on business growth

In the above Anova and regression table the p-value is less than 0.05 for the bold values indicating that it is significant so we conclude that there is influence of business External factors on business growth over the past three years. 


\section{Result and discussion}

Initially we created two hypotheses

Ho: There is no influence of business External factors on performance of IT entrepreneurship

Ha: There is strong influence of External factors on performance of IT entrepreneurship

During our analysis for the first dependent variable ( DV: Business profit grown for last 3 years ), An ANOVA analysis was performed and the results are displayed in table

4. The sum of squares reflects the variances and the ratio of the regression sum to the total sum: 187.773/ 209.595=

.896 which is the $\mathrm{R}$ square as shown in the table. 3 model summaries.

In the Anova analysis, 187.773 is the proportion of the total scattering, which is explained by the regression model. 21.822 quantifies the proportion of variance that cannot be explained by the regression model. 209.595 is the total scattering.

Based on the sum of squares as an unstandardized measure for the variance, the variance is further measured by the Ftest. The F-test checks whether the predictors are suitable for predicting the criterion. The F-test is based on a decomposition of the variance of the criterion in a declared and undeclared part. For this model, the F-ratio is 113.706. This results in a p-value of 0.000 . This gives an overview whether the model can predict the business success significantly well. Since the p-value of $0.000<0.005$, the null hypothesis should be rejected. The null hypothesis Ho says, that There is no influence of business External factors on performance of IT entrepreneurship.

In addition to that, the multiple regression shows the impact of each single independent variable on the dependent variable. Furthermore, the analysis can show how the dependent variable changes if the independent variables change and therefore delivers a prognosis.

The analysis shows that the factors which has most significant impact towards business profit as they have

$<0.05 \mathrm{p}$-value with positive significance

1. Impact of economic condition (1.001)

2. Impact of Media (0.112)

3 . Impact of competitive factor (0.088)

On the above factors apart from economic condition other two factors have lean relationship with business growth. It means stronger economic factor has strong influence over business performance

The below factors having negative impact of significance towards the growth of business,

$$
\begin{array}{ll}
\text { 1. } & \text { Technological Factor }(-0.128) \\
2 . & \text { Legal factor }(-0.084) \\
3 . & \text { Local Climate }(-0.065)
\end{array}
$$

Since the technological, legal and climate is having $>0.3$ impact, so they have very narrow and linear relationship with business growth.

\section{Conclusion}

For every entrepreneurship it is important to understand the ecosystem and identify the external factors which has max impact towards the formation of business strategy. In this study we have seen economic factor plays a major role on employment, wages, inflation, customer confidence. The factor of media plays major role on business promotion, marketing and consumer centric relationship. Competitive factor helps any entrepreneurships to understand the position of their solution of product compared to other enterprises offering similar solution. The competitive factor plays major role on shape up solution, customization, price and branding.

\section{References}

[1] International Journal of Advanced Research in Engineering and Technology (IJARET) Volume 9, Issue 6, NovemberDecember 2018, pp. 236-240, Article ID: IJARET_09_06_025 Available online at http://www.iaeme.com/IJARET/issues.asp ?JType $=$ IJARET $\&$ VType $=9 \&$ IType $=6$ ISSN Print: 0976-6480 and ISSN Online: 0976-6499

[2] IOSR Journal of Business and Management (IOSR-JBM) e-ISSN: 2278- 487X, p-ISSN: 2319-7668. Volume 16,

Issue 5. Ver. III (May. 2014), PP 48-50

[3] A Study on Impact Of Subjective Norms On Entrepreneurial Intention Among The Business Students In Bangalore by J.Krithika1

Dr.B.Venkatachalamhttps://www.forentre preneurs.com/why-startups-fail/

https://discuss.analyticsvidhya.com/t/differ ence-between-r-square-and-adjusted-rsquare $/ 264 / 3$

[4] Why Startups Fail And What You Can Do To Beat The Odds Kindle Edition by George Meszaros

[5] All In Startup: Launching a New Idea When Everything Is on the Line Kindle Edition by Diana Kander

[6] Why Startups Fail: And How Yours Can Succeed by David Feinleibhttp://www.forentrepreneurs.com/ why-startups-fail/

[7] Technology Innovation Management Review, January 2018 (Volume 8, Issue 1)

[8] Technology Entrepreneurship in Emerging Markets: An Exploration of Entrepreneurial Models Prevalent in India by Shiv S Tripathi and Mita Brahma

[9] IMPACT OF SOCIAL-CULTURAL FACTORS ON ENTREPRENEURS IN 
INDIA by Ankita Barik , Bhavesh Vanparia, Lal Bihari Barik

[10] SPATIAL DETERMINANTS OF ENTREPRENEURSHIP IN INDIA Ejaz Ghani William R. Kerr Stephen D. O'Connell

[11] NATIONAL BUREAU OF ECONOMIC RESEARCH 1050 Massachusetts Avenue Cambridge, MA 02138https://www.entrepreneur.com/articl e/236999

[12] Technology Entrepreneurship Ecosystem in India: Findings from a Survey by Ruchita Gupta1 ,Karuna Jain1

,AnandKusre2, Kirankumar S. Momaya of National Institute of Industrial Engineering

(NITIE),https://www.cbinsights.com/resea rch/startup-failure-reasonstop/https://www.spiderg.com/8accounting-problems-facedstartups/https://www.forbes.com/sites/supa rnadutt/2017/05/18/startups-in-india-faildue-lack-of-innovation-according-to-anew-ibmstudy/\#60463065657https://www.moneyw eb.co.za/mybusiness/why-do-70-to-80-ofsmall-businesses-fail-within-five-years/

[13] National Policy on Skill Development and Entrepreneurship ReportThe theory of entrepreneurship modeStart up policy (2015-2020) by government of Karnatakahttps://repository.up.ac.za/bitstre am/handle/2263/28708/Complete.pdf?sequ ence $=9$

[14] IMPACT OF MOTIVATIONAL FACTORS OF NASCENT ENTREPRENEURS ON BUSINESS SURVIVING SUCCESS by Christoph Ernst Wilken Kisker Submitted for the Doctoral Degree in Management Science UNIVERSITY $\mathrm{OF}$

LATVIAhttps://edge.alluremedia.com.au/ uploads/businessinsider/2015/07/Fear-offailure-around-the-world.jpg https://www.go-globe.com/blog/startups/ http://www.thehindubusinessline.com/info -tech/90-startups-in-india-fail-within-5years-ibm/article9704251.ece
[15] Comparing the Entrepreneurial Ecosystems for Technology Startups in Bangalore and Hyderabad, India by $\mathrm{M} \mathrm{H}$ Bala Subrahmanya Technology Innovation Management Review July 2017 (Volume 7, Issue 7)

[16] Licensee MDPI, Basel, Switzerland. This article is an open access article distributed under the terms and conditions of the Creative Commons Attribution (CC BY) license (http://creativecommons.org/licenses/by/4. 0/Factors Affecting Entrepreneurship and Business Sustainabilityby Ana Tur-Porcar 1,* ID , Norat Roig-Tierno 2,3 and Anna Llorca Mestre 4Entrepreneurship theories and Empirical research: A Summary Review of the Literature by Kwabena Nkansah Simpeh, European Journal of Business and Management www.iiste.org ISSN 2222-1905 (Paper) ISSN 2222-2839 (Online), Vol 3, No.6, 2011

[17] Building a Concept of Entrepreneurial Control Hanif Hanif, Abdulah Rakhman, Muhammad Nurkholis, TEM Journal. Volume 8, Issue 4, Pages 1198-1206, ISSN 2217-8309, DOI: 10.18421/TEM84- 13, November 2019

[18] Factors Influencing Project Success: A Qualitative Research by Nermina Durmic, TEM Journal. Volume 9, Issue 3, Pages 1011-1020, ISSN 2217-8309, DOI: 10.18421/TEM93-24, August 2020.

[19] Startup innovation capability from a dynamic capability-based view: A literature review and conceptual framework by Samia El Hanchi1, Lamia Kerzazi2

[20] The relationship between a comprehensive strategic approach and small business performance Ralph I. Williams Jr.1, Scott C. Manley2, Joshua R. Aaron3, Francis Daniel4 in journal of small business strategy

[21] An Everlasting Battle between Theoretical Knowledge and Practical Skills? The Joint Impact of Education and Professional Experience on Entrepreneurial Success by Agnieszka Kurczewska, Wirginia Doryń, 
Dorota Wawrzyniak, EBER.2020.080212, 2020, Vol. 8, No. 2

[22] Entrepreneurial Strategy Stimulating Value Creation: Conceptual Findings and Some Empirical Tests by Wojciech Dyduch, EE concept recognizes the importance of territorial environments for productive, 2019, Vol. 7, No. 3

[23] The Performance of High-Growers and Regional Entrepreneurial Ecosystems: A Research Framework by Marta Gancarczyk, EBER.2019.070306, 2019, Vol. 7, No. 3

[24] The Four Models of Corporate Entrepreneurship By Robert C. Wolcott and Michael J. Lippitz(See, for instance, R. Gulati (introduction), "How CEOs Manage Growth Agendas," Harvard Business Review 82 (July-August, 2004): 124-132.)

[25] (Corporate Strategy Board, "Stall Points: Barriers to Growth for the Large Corporate Enterprise" (Washington, D.C.: Corporate Strategy Board, 1998).

[26] Entrepreneurial Mindset: A Synthetic Literature Review by Christiane Naumann, EBER.2017.050308 2017, Vol. 5, No. 3

[27] Analysing the Role of Framework Conditions Influencing International Entrepreneurial Opportunity Identification Process by Yonni Angel Cuero Acosta, Richard Adu-Gyamfi, Md. Noor Un Nabi, Utz Dornberger, EBER.2017.050301, 2017, Vol. 5, No. 3

[28] The Concept of Technological Entrepreneurship: The Example of Business Implementation by Ewa Badzińska, EBER.2016.040305, 2016, Vol. 4, No. 3

[29] The role of ethical behavior and entrepreneurial leadership to improve organizational performance Anak Agung Dwi Widyani, Nengah Landra, Nengah Sudja, Mateus Ximenes \& I Wayan Gde Sarmawa, ISSN: (Print) 2331-1975 (Online) Journal homepage, Cogent Business \& Management
[30] Factors that Positively Influence the Initiation of a Business by Alice Reissová, Jana Šimsová, Kateřina Kovářová, Radek Šimanovský, TEM Journal. Volume 8, Issue 2, Pages 486-491, ISSN 2217-8309, DOI: 10.18421/TEM82-23, May 2019.www.thehindubusinessline.comhttps: //shodhganga.inflibnet.ac.in/bitstream/106 03/6702/9/09_chapter\%203.pdfhttps://ww w.entrepreneur.com/ \& https://www.cbinsights.com/

[31] The impact of external environmental on business process management and organizational performance by Wai Peng Wong, Noor Hazlina Ahmad, Aizzat Mohd. Nasurdin \& Marini Nurbanum Mohamad (https://link.springer.com/article/10.1007/s 11628-013-0207-9)

[32] Critical Success Factors in Business Performance Management-Striving for Success by Thilini R. Ariyachandra \&Mark $\mathrm{N}$. Frolick (https://www.tandfonline.com/doi/abs/10.1 080/10580530801941504) 